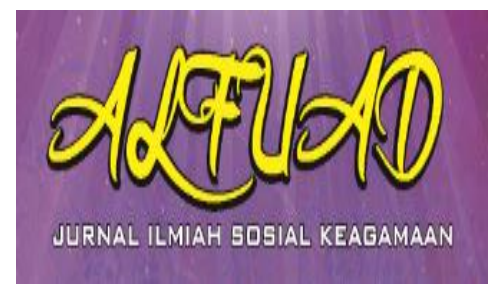

ALFUAD JOURNAL, 5 (1), 2021,(11-23)

(E-ISSN 2714-7606 P-ISSN 2614-4786 )

Available online at

http://ecampus.iainbatusangkar.ac.id/ojs/index.php/alfuad

\title{
The Advantages of Social Solidarity to be an Ideal Leader according to Ibnu Khaldun
}

\author{
Kasmuri Selamat*) \\ Universitas Islam Negeri Syarif Kasim \\ Riau, Indonesia \\ E-mail: kasmuriselamat@gmail.com

\section{Irma Handayani} \\ Universitas Islam Negeri Syarif Kasim \\ Riau, Indonesia \\ E-mail: irmah5138@gmail.com
}

\section{Akhyar Hanif}

Institut Agama Islam Negeri Batusangkar, Indonesia

E-mail: akhyarhanif@iainbatusangkar.ac.id

*) Corresponding Author

\begin{abstract}
The ideal leader is an expectation for every society in the world. Leadership is a relationship between the influence of the leader and the one being led. Leadership also functions to execute power to invite, influence, guide, mobilize and build other people to do something to achieve certain goals. To implement, Islam provides normative and philosophical bases on the principles of leadership. These principles include deliberation, fairness, gentleness, freedom of thought, synergy in building togetherness. The principles taught by Islam are in line with the thoughts of one of the Islamic philosophers, Ibn Khaldun. Furthermore, he emphasized that the social solidarity factor is crucial to become an ideal leader.
\end{abstract}

Keywords: Social Solidarity, Ideal Leader, Ibnu Khaldun

\section{INTRODUCTION}

In a group, community, society, nation and even a state, in essence the leader has a very important position. Even the position of a leader greatly determines the progress of a nation or country. In the hands of the leader, the future and success are at stake. The expected leader is a personal figure who has the skills and character so that he is able to carry out his leadership mission in moving the community to achieve a goal (Kartini Kartono, 2008).
According to Islamic teachings, what is meant by a leader is a servant for the community who is burdened with the mandate to take care of all the problems of the ummah so that his accountability does not only touch the problems that exist on the surface of the "earth" but also relates to those in the "sky". In this case, a leader must combine the Divine and non- Divine sides. Mentioned in a hadith that means.

"Each of you is a leader and every one of you will be questioned about his leadership. (Narrated by Bukhari: 893). From the explanation of the hadith above, 
it can be concluded that a leader has a very important role, as in an Islamic society building, the leader is in a decisive position on the journey of his ummah. precisely that, Islam views that leadership has a very strategic position in the realization of a society that is Baldatun Thoyyibatun $\mathrm{Wa}$ Rabbun Ghafur (Surah 34:15).

Regarding this leadership, Ibn Khaldun, a Muslim philosopher-sociologist wrote in his work called al-Muqaddimah which deals with the characteristics of leaders and leadership as well as the characteristics of an ideal government.

Not only with theory, but also based on practice in the field, Ibn Khald un understands very well the intricacies of the world of government and politics. His political experience started from $751 \mathrm{H}$ to $776 \mathrm{H}$, it can be said that Ibn Kald un's life was mostly involved in politics and government. Because he is in this field, he often moves from one country to another, from Maghreb to Andalusia. He even served as a judge, minister, and secretary of state. It was this experience that motivated him to write in his book Muqaddih about the ideal government or leader.

The function of leadership is sometimes as a basis for exercising government power in terms of influencing, inviting, directing, moving and building other people to do something (Kartini
Kartono, 6). Instead, as a leader, you must understand these basics. Besides that, leadership cannot be separated from the fact that leaders and those being led are part of life (Ainun Najib, 1).

A leader according to Islamic teachings must be qudwah (exemplary), this is done not only in the form of speech and advice, but also exemplary in the form of good temperament or behavior. As Allah's Word means: "Indeed, the Messenger of Allah is a good role model for you (that is) for those who expect (the mercy of) Allah and (the coming of) the Day of Resurrection and who remember Allah a lot. (Qs. 33, 21).

A leader must also consult in making a decision or policy, act not on the basis of his own will or perception, and let alone only based on the perception of the group or its supporters.

Being fair does not choose one or any party must be in a leader. To realize this, a leader must be guided by religious teachings. Thus, the law will be strong in determining justice. Both when dealing with strong people and weak people. The nature of gentleness must also be possessed, love and pray for each other, as exemplified by the Prophet Muhammad in his leadership.

The four principles that must be possessed in the figure of a leader as described above, are in accordance with 
the criteria put forward by Ibn Khaldun in his book Al-Muqaddimah. The first is knowledge, a leader must have the knowledge to run the government. Both knowledge is obtained through experience he has gone through, and others. Second, have a fair nature. Third, have the ability. At least the benchmark for choosing a leader who has the ability is to look at the track record of what he has done. Fourth, physically and mentally healthy. In addition to these criteria, a leader must also have spiritual characteristics (morals or morals) and mental leadership. Because the success of a leader and what he leads is largely determined by the personality, or character possessed by the leader.

Regarding the ideal leader, namely how a good leadership model must be owned by a leader, in this case Ibn Khaldun did not explain in detail. Ibn Khaldun only explained in general about the characteristics of Islamic leaders. He put more emphasis on social solidarity ('ashabiyah). According to him, a leader must be able to have strong leadership characteristics and have the influence of power and authority to be able to build this solidarity.

He said that an ideal leader is not enough just to have charisma in front of his people, but also to have other criteria that will be able to deliver him as an ideal leader. Because leading can only be carried out with power, the social solidarity possessed by the leader must be stronger than other solidarity, so that he gains power and is able to lead his people perfectly (Ibn Khaldun, 156).

Based on the above background, the author is interested in further researching related to the issue of ideal leadership according to Ibn Khaldun.

\section{METHOD}

This research is a library research, namely by conducting a literature review, either through reading, researching, understanding books related to the title of the research which are library in nature. This research also departs from the descriptive method, which in general descriptive research provides an overview and interpretation of a study. As according to Whitney (1960), the descriptive method is a fact-finding with the right interpretation (Nasir, 53). This study uses a historical-factual research model that concerns the character.

\section{RESULT AND DISCUSSION}

Ibn Khaldun's full name is Aliuddin Abdurrahman bin Muhammad bin Muhammad bin Hasan bin Jabir bin Muhammad bin Ibrahim bin Abdirrahman bin Khalid bin Usman or better known as Ibn Khaldun (Abd. Al-Rahman Khaldun, 1). The land where he was born in Tunisia on the 1st of Ramadan 732 H./27 May 
1332 AD (Syamsul Nizar, 96). Ali Abdul Wahid Wafi 'also explained that the nickname assigned to Ibn Khaldun was a lineage that was connected to his 9th grandfather, namely Khalid bin Uthman, a friend of the Prophet ('Ali abd al-Wahid Wafi, 9). His father named Abu Abdullah Muhammad, an expert in Arabic language and literature, later died during the tha'un (the black-death) epidemic in $749 \mathrm{H}$.

As a child, Ibn Khaldun grew and developed in an educational environment that was guided directly by his father in studying the Qur'an and at the same time memorizing it. From the education raised by his own father, Ibn Khaldun was able to memorize the Qur'an at a young age. Not only that, Ibn Khaldun also studied various kinds of qira'at, so that he was able to master qira'at at al-sab'ah fluently (Syamsul Nizar, 96). In addition to studying the intricacies of the Qur'an, he also studied language, poetry, commentary, hadith, law, and even philosophy with several scholars from Andalusia who migrated to Tunisia.

Besides his father as his first teacher, he learned linguistics from several teachers, among the teachers who were very important for Ibn Khaldun were; Abu 'Abdillah Muhammad Ibn al-Arabi alHasayiri and Abu al-'Abbas Ahmad Ibn alQusar and Abu 'Abdillah Muhammad Ibn Bahar. He studied Hadith through
Syamsuddin Abu Abdillah al-Wadiyasi. While fiqh he studied with several teachers such as Abu 'Abdillah Muhammad alJiyani and Abu al-Qasim Muhammad alQasir. He also studied philosophy, theology, logic, natural sciences, astronomy and mathematics through a teacher whom he greatly admired Abu 'Abdillah Muhammad Ibn Ibrahim al 'Abili. (Kasmuri Selamat, 124).

Imam Malik's book al-Muwatta' was studied by Abullah Muhammad bin Abdussalam. In addition, he also often mentions the names of other teachers, including Muhammad bin Sa'ad bin Baraal al-Anshary, Muhammad bin Syawwas azZilzaly, Muhammad bin Bahar, Muhammad bin Jabir al-Qaisy, Muhammad bin Sulaiman ash-Syatthi, Ahmad Zawawy, Abdullah bin Yusuf bin Ridwan al-Maliqi. (Muhammad Kosim, 17).

Not only is he known as a figure who masters various fields of science, he is also active in politics, according to his ambition from a young age to be able to become a leader or rule a caliphate area and dream of Islam so that it returns to its heyday, even during his life he had experienced and involved himself with political matters, even his prowess in the world of politics can be seen from a number of important positions he had been given while in Morocco, Andalusia and 
Egypt. Some important positions such as: Kitabatul Allamah (Master Of the Signature), namely secretary or speechwriter during the time of Sulthan Fadl with Prime Minister Abu Muhammad Ibn Tafrakin in $751 \mathrm{H}(1350 \mathrm{AD})$, member of the scientific council in Fez in 755-758, became katib (secretary) during the reign of Sultan Mansur Sulaiman in 760, became Khittah al-Mazhalim, which was in charge of examining and determining the law for perpetrators of crimes during the $\mathrm{Abu}$ Salim Abu Hasan era, became a diplomat/ambassador of the State during the reign of Sultan Muhammad bin Yusuf Ismail bin Ahmar an-Nashri in $765 \mathrm{H}$, became a Hijabah during the time of $\mathrm{Abu}$ Abdillah Hafsy and Abu Abbas in Bijayah, Lower Morocco in 767, and took turns being a lecturer in Maliki jurisprudence and a judge in Egypt (Ibn Khaldun, 253254).

As explained in the discussion above, that Ibn Khaldun is not only known as a person who is actively involved in the political field directly, but is also noted as a very active person in writing. After he spent approximately 15 years as an employee and a politician, Ibn Khaldun finally decided to quit the world of politics and switch his focus to composing and writing activities. He took this decision because he began to feel tired of the conflict in the world of politics which is increasingly showing feuds. However, this writing activity did not only start when Ibn Khaldun decided to leave politics. However, it is recorded in its history that Ibn Khaldun even started this writing activity when he was still in his education in Morocco, at that time Ibn Khaldun was often actively involved in scientific activities. (Ali Abd. Wahid Wafi, 42). Ibn Kahaldun ended his age on the 25th of Ramadan 808 H. or March 19, 1406 AD. His death was sudden and he was buried in a Sufi cemetery outside Bab al-Nasr Cairo, at the age of seventy-six years (Abd. AlRahman Badwi, 27).

As one of the most prolific Islamic intellectual figures, Ibn Khaldun produced many scientific works, as evidenced by his scientific works that received great attention from scientists and other intellectuals (Kasmuri Selamat, 134).

These scientific works are generally very difficult to trace because they are not explained in his greatest work, namely the Muqaddimah, which is described only in small books. However, some of Ibn Khaldun's works that have been traced include: Talkhis al-Muhassal li Fakhr alDin, al-Razi.

Not only did he write papers from the results of his own thoughts, but he also wrote a summary of the results, such as a summary of a theological book by Fachruddin ar-Razi which he gave the title 
Lubab al-Muhashshal fi Ushuluddin (752 H) or $(1351 \mathrm{H}) \mathrm{M})$ (Abdullah Cheming, 36-37). Apart from that he also summarized a lot of Ibn Rushd's works and described them on logic with interesting views, as well as the work of al-Muhassal Imam Fahruddinal-Razi, compiled a work of arithmetic, commented on a work on fiqh proposals with a very good description (Kasmuri Selamat, 136-137).

Another work is said that Ibn Khaldun also wrote a small book, the book describes in detail about the Maghreb country which he compiled to fulfill requests from east Lenk (Zainab alKhudhari, 41).

\section{The characteristics or traits of a leader according to Ibn Khaldun}

One part of human nature is the need for a leader. Because, when humans are already in a group, at that time he will need someone who is dominant and most superior among them to be expected to be able to guide, direct, or even treat them fairly. In connection with this, Ibn Khaldun in his Muqaddimah argues, that this is because it is impossible for humans to live their lives in an anarchic situation without a head of state who can maintain their survival (Ibn Khaldun, 229). Instead, they really need a controller who is in charge of ordering and directing those who are called leaders.
To be appointed as a leader, of course there are several conditions that must be met, so that with the conditions he has it makes other people feel confident that he is indeed worthy to be a leader.

Trust is the main requirement that must exist in a leader, so that with this trait a leader will not do something only concerned with his personality, but he does for the benefit of the people or society.

In this regard, Islam places great emphasis on the behavior or noble character possessed by a leader so that the leader then makes his leadership a mandate from God. Such things, said Ibn Khaldun, he could find through experience in understanding the nature of truth by paying attention to the events that occurred and asking for help from scientific experts. So in essence a leader, said Ibn Khaldun, must be a knowledgeable person. (Muhammad Kosim, 65).

As one of the intellectuals in Islam, Ibn Khaldun studied a lot about social issues, including providing views related to the ideal leader. Although his views are not much different from those of Islam, there are several things that dominate his thinking.

In the view of Islam, a leader must imitate the personality exemplified by the Prophet Muhammad. In fact, when we talk about the personality of a leader, in essence we are talking about the 
personality of the Prophet S.A.W. who is allegedly a human being who is able to spread grace to the whole world.

Leaders in Islam as exemplified by prophet Muhammad are leaders who are not only in the realm of world mechanisms, but, a leader besides functioning to maintain the welfare of the people, his existence is also a leader (faith) whose all actions (morality) will guided and become a role model to be used as a reference for all its people (Syamsul Nizar, 102). For this reason, according to Ibn Khaldun, a leader must first be a wise and wise human being, and inherit the attributes of divinity as the Messenger of Allah.

In his Muqaddimah, Ibn Khaldun mentions several conditions that must be met by a leader. To be a leader, one must be knowledgeable, including the implementation of Allah's laws, justice, ability, no sensory defects and from Quraish derivatives (Ibn Khaldun, 238).

The leadership principles in Ibn Khaldun's thinking are normatively not much different from the basic principles of Islamic teachings, such as qudwah, deliberation, gentleness, fairness, freedom in thinking, building togetherness and optimizing the resources they have. All these aspects of leadership can also be found in Ibn Khaldun's muqaddimah book. From several existing aspects, Ibn Khaldun puts forward things related to social solidarity, because this social solidarity will later affect other aspects of a government. Here are some aspects that need to be considered by the ideal leader in Ibn Khaldun's thought:

Social Solidarity (Ashabiyyah) According to Ibn Khaldun, the ideal leader must come from his own circle, have the ability to control his citizens, have power, authority, and authority. This is what is called al-mulk (Hasaruddin, 482). Al-Mulk which if here as a basic step or a must that must be owned by a leader, because a new leader can be considered 'there' he has power. To gain power, according to Ibn Khaldun, is to master social solid arity.

Leadership without social solid arity is tantamount to sheer nonsense. Because a new leader exists because of power, and power exists because of social solidarity (Ibn Khaldun, 157). That is, in general there will be new leaders, because the urge to dominate, lead can only be done with power, so to gain power one of the efforts that must be made is by establishing good cooperation which is built on the basis of social solidarity. So, the leader in this case, must have strong social solidarity so that he is able to gain power and be able to lead his people perfectly (Ibn Khaldun, 159). According to him again that no one can rule a nation or generation, except by mastering social solidarity (Ibn Khaldun, 
243). Because social solidarity can guarantee a meeting and an agreement that a ruler wants to reach for the same purpose, to defend the country and defeat the enemy (Ibn Khaldun, 266).

What Ibn Khaldun stated in this case is not unreasonable, this is because during his lifetime with a period of disintegration, and guided from the Islamic past about how the historical struggle of the kingdom which by various kinds of betrayal and identical with war and killing each other in order to take power. So Ibn Khaldun concluded the importance of the meaning of social solidarity or what is called 'ashabiyah. Where, when a power has strong 'ashabiyah or social solidarity, it will be able to form a strong union and be able to maintain its power.

Social solidarity is seen as a divine secret factor that controls the people so that they are not divided and hostile to each other which ultimately raises awareness of living together, caring for each other, helping each other so that Islamic brotherhood continues to survive and become stronger in accordance with the teachings of Islamic law.

If there are enemies who want to disrupt unity, then the social solidarity that has been established will become a strong wall of defense. Because social solidarity can also lead to the ability to hold back in the face of challenges. In fact, Ibn Khald un emphasized that the value for someone who governs his people does not lie in his handsome cut and good looks, broad knowledge and sharp brain, but it is his relationship with the people that is very decisive (Ibn Khaldun, 230).

In fact, if someone wants to be an ideal leader, the leader must have power, because leadership is not 'de jure' power but is 'de facto' power and leadership is obtained by victory, namely by the use of force and that power is social solidarity.

The strength possessed by 'ashabiyah (social solidarity) is even able to defeat the power built by religion, even according to Ibn Khaldun, shari'ah itself is realized through social solidarity, thus the absence of social solidarity is also able to eliminate shari'a (Ibn Khaldun, 249).

From Ibn Khaldun's framework, it can be seen that 'ashabiyah (social solidarity) is very closely related to other aspects of human life, so it can be concluded that 'ashabiyah (social solidarity) is the main root for all problems related to human life. For example, 'ashabiyah can affect the religious, state, political and economic sectors. As Ibn Khaldun said that for the survival of a country, the 'ashabiyah factor is considered an essential factor.

Being gentle according to Ibn Khaldun' gentle attitude is an attitude that a leader should have, because a gentle 
attitude can melt hearts and can make others obedient. In addition, being gentle is a recommendation from Islamic teachings, because Islam is a religion that is calm, gentle, and opposes every form of violence. Ibn Khaldun in his book Muqaddimah says; if the leader is gentle with his people, likes to forgive their mistakes and mistakes, then of course the people will trust and depend on him for protection, besides that the people will also love him and are willing to fight to the last drop of blood to fight for the country. from enemy attacks (Ibn Khaldun, 231).

A ruler is very closely related to moral nobility, in fact a gentle attitude is highly recommended, because in essence a ruler is a consequence of the existence of high morals within him (Rahman Zainuddin, 202). With this gentle attitude will also give birth to a leader who is simple at heart and will avoid various kinds of disobedience and do wrong to his people.

This kind of leader will certainly get the love of the people and the people will be happy to sacrifice body and soul for their leader. In addition, the people who are led will feel safe and comfortable being led by the leader. Thus, there is very little possibility of rebellion, because rebellion usually occurs because of the rude attitude of a leader.
Seeing how important it is to be gentle for a leader, Ibn Khaldun emphasized that "the requirement for a good government or leader is that the person who governs defends his people and is generous to them" (Muhammad Murdiono, 40).

\section{Obeying the Commandments of Religion}

According to Ibn Khaldun, a leader must understand and understand religion so that later his leadership will be based on things that have been outlined by religion. The goal is none other than that the State he leads is based on religious teachings, thus meaning that his leadership is also under the supervision of God as the One who gives the law. In addition, because religion, especially Islam is a religion that teaches and praises the qualities of justice, honesty, and so on that must be possessed by a leader.

Leadership based on religion is very important in building the concept of social solidarity. Because according to Ibn Khaldun the spirit of people's unity formed through the role of religion cannot be matched by the spirit of unity formed by other factors. Besides that, in essence, social solidarity itself will not exist without the role of religion, because religion has a vision as a forum for the unity of human differences, so that with religion a 
common goal is formed for the sake of upholding the religion.

Paying attention to the people's sovereignty is the main component for a leader. In fact, it is very important for a leader to pay attention to the needs and welfare of his people. A leader has a responsibility to protect his people not only that, a leader also has to oversee everything that includes livelihoods and transactions together, such as food, scales, and measures to prevent fraud. Because the people are the power of the leader. It is the people who will unite to help him, such as helping him in suppressing the rebellion (Ibn Khaldu, 222). Instead, the leader must defend the interests of his people and be fair to him (Ahmad Khalwani, 116).

A leader according to Ibn Khaldun must defend and protect the people from enemy attacks. He must enforce the law against his people and take care that they do not become enemies and attack each other because of property. This includes security and human traffic. He must also try to make the people he leads act and do their best for the sake of their respective interests. Besides that, a leader must also supervise general problems such as living, muamalat issues such as food problems and others (Osaman Raliby, 200).

\section{The Ideal Leader According to Ibn}

\section{Khaldun}

From the description above, at least it has been illustrated what an ideal leader according to Ibn Khaldun looks like. The ideal leader in addition to having to meet requirements such as knowledge, be fair, have the ability, not disabled, come from the Quraysh tribe, and must have good leadership management that can prosper the people.

Broadly speaking, the essence of the ideal leader is indeed not much different from what is specified in Islam, that the essence of a leader is, the caliph who acts as a substitute or carrier of the Shari'ah (Muhammad), with the obligation to take care of religion and worldly leadership. Ibn Khaldun, 264). In addition, leaders must also pay attention to commendable traits and morals such as gentle and simple at heart, so that these qualities will give birth to authoritative leadership.

Even though he already has noble character such as gentle and simple nature, for Ibn Khaldun it is not enough capital to become an ideal leader, the leader must also have advantages in managing his leadership such as prioritizing the people by paying attention to relations with the community through social solidarity. Therefore, the commendable nature that has been formed in a leader needs to be 
equipped with his expertise in managing his relationship with the community.

For someone who already has strong social solidarity and is decorated with a commendable character and carries out religious laws, such a person means that he is ready to assume responsibility as a leader and has the competence to carry out this noble mandate. Social solidarity here is a must, because as explained above, aggressive and defensive actions can only succeed with the help of social solidarity (Osaman Raliby, 190). Social solidarity for Ibn Khaldun will also not be so strong if it is not balanced with other elements. So, in this case, the power of social solidarity will be strengthened by the power of religious spirit.

Ibn Khald un describes leadership in his writings; "O King, the sovereignty of a country will be fulfilled through religious law, by obeying Allah's commands and avoiding His prohibitions. Shari'ah will only be established or realized through sovereignty, while sovereignty will not be established without it through men. Humans will only be upright if through the help of wealth, while wealth will not be obtained without entrepreneurs. Entrepreneurs will also only exist if justice is upheld, while justice is a scale that is enforced among mankind (Ibn Khaldun, 361).
From Ibn Khaldun's expression, it has at least given a brief description that a leader must pay attention to, that as a leader he must realize, being a leader is a mandate from Allah and then he must be fair and also need to pay attention to worldly efforts.

If you pay attention to what has been expressed by Ibn Khaldun, it turns out that for him to become an ideal leader it is very much determined by social solidarity, with this social solidarity will determine the strength and weakness of a sovereignty, as well as the length or short life of a country. The concept of social solidarity put forward by Ibn Khaldun for the author is a brilliant thought produced by Ibn Khaldun and will be very useful and can be an additional concern for the government, where politics today sometimes has started to dry from the principle of social solidarity. However, despite this concept of social solidarity, apart from being the hallmark of Ibn Khaldun's thought, there are also weaknesses as he said that the wrong social solidarity can lead to blind fanaticism.

From another angle, if you look at it, the concept of an ideal leader according to Ibn Khaldun, according to the author, is still general, as is his opinion about the qualities or characteristics that a leader must possess. The ideal leader according to 
him is a figure whose position is clear as a leader of the world and the hereafter as regulated in Islam.

He did not give a definite picture of, for example, what kind of leadership is recommended and what a leader needs to implement in his leadership. So that the concept of leadership is still universal or nothing more than a general description of the leadership that is in the Qur'an and which has been exemplified by the Prophet Muhammad. Then, the Quraysh tribe which was used as a condition by Ibn Khaldun, was also no longer relevant to the times. Because in today's era the superiority of a leader is not seen based on a particular tribe, but a superior ruler can come from any tribe depending on how he is born and his system in leading.

\section{CONCLUSION}

Ibn Khaldun with the full name Waliuddin Abdurrahman bin Muhammad bin Muhammad bin Hasan bin Jabir bin Muhammad bin Ibrahim bin Abdirrahman bin Khalid bin Usman or better known as Ibn Khaldun, was born in Tunisia on 1 Ramadan 732 H./27 May 1332 AD.

Ibn Khaldun is one of the figures of Islamic philosophy, in his life much involved in the world of practical politics, which then made the philosophy of history as his method of thought. Al-Muqaddimah is a manifestation of his extraordinary thinking. In this spectacular work, Ibn Khaldun also mentions how to become an ideal leader. The leader for Ibn Khaldun is a figure who is able to be the best role model for his people, therefore for Ibn Khaldun a leader in his leadership cannot be separated from the values of kindness and full of compassion for his people. Leaders for Ibn Khaldun must use their power with fair power, friendly, gentle, so that those they lead do not feel pressured.

For Ibn Khaldun, a leader must first meet several requirements such as: Knowledge ('ilm), including wise in making decisions. Justice, ability, includes the ability to protect the trust that has been given to him. Freedom of the senses and limbs from disability. Descendants of the Quraysh. In addition, there are several things that a leader needs to pay attention to, when he has gained power, such as paying attention to his community with 'ashabiyah (social solidarity) affiliations, being gentle, adhering to the right religion, and paying close attention to the economy of the community. 'Ashabiyah (social solidarity) became an important point in Ibn Khaldun's thought related to the Quraysh tribe which was used as a condition for his ideal leader. For Ibn Khaldun, the Quraysh tribe is a superior tribe from other tribes and that includes in terms of social solidarity. 


\section{REFERENCES}

Badwi, Abd. Al-Rahman. (1962). Mu'allafat Ibn Khaldun. Kairo.

Khalwani, A. (2019). Relasi Agama dan Negara dalam Pandangan Ibn Khaldun. Jurnal Revolusi No.2.

Najib, Ainun. Konstruksi Pemimpin Ideal untuk Indonesia. Jurnal Agama dan Hak Azazi Manusia, No.1.

Wafi, Ali Abd. Wahid. (1985). Abd alRahman Ibn Khaldun, terj. Akhmadi Thaha. Jakarta: Grafiti Pers.

Issawi, Charles. (1976). Selection From The Prolegomen of Ibn Khaldun of Tunis. Terj. Mukti Ali. Jakarta: Tinta Mas.

Hasaruddin. (2010). Karakteristik Pemikiran Politik Ibn Khaldun. Jurnal Al-Fikri. No.3.

Madkur, Ibrahim. (1962). Ibn Khaldun alFilosuf dalam A'mal Mahrajan Ibn Khaldun. Kairo.

Khaldun, Ibn. (tt). Muqaddimah. Kairo.

Kartini Kartono. (2011). Pemimpin dan Kepemimpinan;

Kepemimpinan Abnormal itu? Rajawali Pers.

Selamat, Kasmuri. (2017). Timbangan Emas Buat Menimbang Gunung: Pandangan Ibn Khaldun Terhadap Filsafat Ketuhanan. Jakarta: Kalam Mulia.

Nasir, Moh.. (2003). Metode Penelitian. Jakarta: Ghalia Indonesia.

Enan, Muhammad Abdullah. (1953). Ibn Khaldun: Hayatuh wa Turasuh alFikri. Kairo.

Murdiono, Muhammad. (2006). Citra Penguasa Ideal dalam Perspektif Politik Ibn Khaldun dan Relevansinya bagi Kepemimpinan di Indonesia. Jurnal Penelitian Humaniora. No. 2.

Farukh, Umar. (1962). Tarikh al-Fikr'l'Arabi. Beirut.al-Maktabah atTijari.

Raliby, Osman. (1978). Ibn Khaldun Tentang Masyarat dan Sejarah. Jakarta: Bulan Bintang.
Zainab al-Khudari. ( 1907). Filsafat alTarikh Ibn Khaldun. Terj. Ahmad Rafi' Utsmani. Bandung: Pustaka. 